\author{
Case Study \\ www.ijrap.net (ISSN:2229-3566)
}

\title{
EFFECT OF AYURVEDIC REGIMEN ON ELEVATED BETA-HCG LEVELS IN HYDATIDIFORM MOLE AFTER INDUCTION OF GARBHAPATA: A CASE STUDY
}

\author{
Poonam Choudhary $* 1, \mathrm{~K}$. Bharathi ${ }^{2}$, Suman Jain ${ }^{3}$ \\ ${ }^{1}$ Lecturer, Department of Prasuti-Stree Roga, National Institute of Ayurveda, Jaipur, Rajasthan, India \\ ${ }^{2}$ Professor and Head, Department of Prasuti-Stree Roga, National Institute of Ayurveda, Jaipur, Rajasthan, India \\ ${ }^{3}$ Consultant Gynecologist, Department of Prasuti-Stree Roga, National Institute of Ayurveda, Jaipur, Rajasthan, India
}

Received on: 21/04/20 Accepted on: 02/06/20

\author{
*Corresponding author \\ E-mail: poonam.18veena@gmail.com
}

DOI: 10.7897/2277-4343.110479

\begin{abstract}
The incidence of Molar pregnancy in India is one in 400 out of them $80 \%$ of the cases are uncomplicated and $20 \%$ are associated with an extensive list of perioperative complications, some of which may be of a critical nature. There is a wide variation in incidence reported worldwide which has been contributed by genetic, environmental and demographic and host related factors. We report a case of a 30-year old female with hydatidiform mole and elevated Beta-HCG level after D \& C which was managed by Ayurvedic treatment regime. Implementation of an Ayurvedic approach with serum BetaHCG levels, ultrasonographic help in success of this case without use of methotrexate.
\end{abstract}

Keywords: Arbudhara kwatha, Beta-HCG, Choriocarcinoma, hydatidiform mole, Raktaja gulma

\section{INTRODUCTION}

A molar pregnancy is a gestational trophoblastic disease ${ }^{1}$ or hydatidiform mole (or hydatid mole, mola hydatidosa). ${ }^{2}$ which grows into a mass in the uterus that has swollen chorionic villi. These villi grow in clusters that resemble grapes ${ }^{3}$. A molar pregnancy can develop when a fertilized egg does not contain an original maternal nucleus and do not develop in fetal tissue. It is categorized as partial moles or complete moles, with the word mole being used to denote simply a clump of growing tissue, or a growth.

More than $80 \%$ of hydatidiform moles are benign. The outcome after treatment is usually excellent. Close follow-up is essential to ensure that treatment has been successful. ${ }^{4}$ In 10 to $15 \%$ of cases, hydatidiform moles may develop into invasive moles. This condition is named persistent trophoblastic disease (PTD). The moles may intrude so far into the uterine wall that hemorrhage or other complications develop. In 2 to $3 \%$ of cases, hydatidiform moles may develop into choriocarcinoma, which is a malignant, rapidly growing, and metastatic (spreading) form of cancer.

Hydatidiform moles should be treated by evacuating the uterus by uterine suction or by surgical curettage as soon as possible after diagnosis, in order to avoid the risks of choriocarcinoma ${ }^{5}$. Patients are followed up until their serum human chorionic gonadotrophin (HCG) level has fallen to an undetectable level HCG is excellent marker for continued trophoblastic activity. Invasive or metastatic moles (cancer) may require chemotherapy and often respond well to methotrexate.

According to Ayurveda molar pregnancy can be correlated with Raktaja-gulma. As per Acharya Sushruta, the treatment of Raktaja gulma is same as Pittaja gulma i.e. Snehan and Madhur dravya Virechana. He also mentioned a specific treatment for Rakta-gulma is Rakta-vibhedana. After Rakta-vibhedana treatment like Raktapradara should be done ${ }^{6}$.
According to Acharya Charaka, in each type of Gulma, the first line of treatment is Vataghna i.e. Snehana - Swedana-Snigdha virechana ${ }^{7}$. According to Acharya Kashyapa it is treated by Niruha basti ${ }^{8}$.

\section{Case report}

This is a case of a 30 year-old lady who visited the Prasuti Tantra and Stree Roga outpatient department (OPD) of National institute of Ayurveda hospital, Jaipur, on March 26, 2019 with the complaints of Nausea during menstruation, lower abdominal pain, White discharge per vagina, reduced appetite and sleep disturbances since 2 month with positive urine pregnancy test. She had her last menstrual period on $10^{\text {th }}$ March 2019 with regular cycle with painless and clotted excessive flow, 4-5 pads per day and interval of 30-35 days, Obstetric history revealed 2 previous normal delivery of 2 male child ages 4 and 8 years. She had history of one induced abortion at Gestational age of 2 month 15 days in November 2018. Her histopathological report showed vesicular mole on 12/11/18.

On examination, the general condition of the patient appeared healthy. Blood pressure (BP) was $110 / 80 \mathrm{mmHg}$ and pulse were $70 \mathrm{bpm}$, No pallor and edema were present, mild tenderness in lower abdomen was present during per- abdomen examination. Per- vaginal examination was withheld. Hematological, biochemical investigations were found within normal limit but her quantitative BHCG was $1212.65 \mathrm{mIU} / \mathrm{ml}$ on $1 / 4 / 2019$, her uterus and adnexa USG were normal.

\section{Treatment protocol}

Considering the fact that she is the follow up case of vesicular mole, she was advised to admission in the Prasuti tantra and Stree Roga inpatient department. Her uterine curettage was done, and endometrium was sent for biopsy. Histopathological examination 
showed increased glands to stroma ratio suggestive of interval endometrium on $3 / 4 / 2019$.

She was advised to take light diet. Cap Giloy, Cap Neem was started as two times per day and Kalka of 2-3 Sadabahar leaf in early morning at empty stomach, Avipatikara Churna 3 gm two times per day 15 min before meal. Again, quantitative Beta-HCG was done on 4/4/2019 which was same as earlier $1212.65 \mathrm{mIU}$ $/ \mathrm{ml}$ and repeated in every 15 days which was very fluctuating. From her next LMP which was on 29/4/19 Tab ovulac-LD OCP was also started. In 21 May 2019 beta-HCG value was 865.28 $\mathrm{mIU} / \mathrm{ml}$ which were same as in April.

Table 1: Sequential changes in the clinical and biochemical parameters and treatment plan

\begin{tabular}{|c|c|c|c|c|}
\hline Day & Date & Complaints & $\begin{array}{l}\text { serum Beta-hCG } \\
\text { value in } \mathrm{mIU} / \mathrm{ml}\end{array}$ & Treatment given \\
\hline Day 0 & 26.3 .19 & $\begin{array}{c}\text { Nausea during menses, Lower abdominal pain } \\
\text { White discharge per vagina, UPT Positive } \\
\text { H/O D \& C in November } 2018 \\
\text { Histopathological report shows vesicular mole }\end{array}$ & & $\begin{array}{c}\text { Avipatikara churna-3 gm } \\
\text { Pittantaka churna-3 gm } 15 \text { min before } \\
\text { meal }\end{array}$ \\
\hline Day 5 & 1.4 .19 & $\begin{array}{c}\text { Weakness, USG- Ut and Ad shows no gestational } \\
\text { sac, Normal study }\end{array}$ & $1212.65 \mathrm{mIU} / \mathrm{ml}$ & $\begin{array}{c}\text { Planned for D\&C } \\
\mathrm{D} \& \mathrm{C} \text { done on } 2.4 .19\end{array}$ \\
\hline Day 7 & 3.4 .19 & $\begin{array}{c}\text { Histopathological examination shows increased } \\
\text { glands to stroma ratio suggestive of interval } \\
\text { endometrium on } 3 / 4 / 2019\end{array}$ & & $\begin{array}{l}\text { Kalka of 2-3 Sadabahar leaf in early } \\
\text { morning empty stomach. Cap Giloy, } \\
\text { Cap Neem } 2 \text { b. d., Avipatikara Churna } 3 \\
\text { gm b. d } 15 \text { min before meal, light diet. }\end{array}$ \\
\hline Day 8 & 4.4 .19 & $\begin{array}{c}\text { Pain in lower abdomen } \\
\text { Burning sensation in urine }\end{array}$ & $1212.65 \mathrm{mIU} / \mathrm{ml}$ & Gokshura churna $3 \mathrm{gm}$ three times a day \\
\hline Day 15 & 11.4 .19 & Relief in previous complaints & $991.94 \mathrm{mIU} / \mathrm{ml}$ & $\begin{array}{l}\text { Gokshura churna Stop, continue } \\
\text { remaining treatment as it. }\end{array}$ \\
\hline Day 27 & 23.4 .19 & & $865.28 \mathrm{mIU} / \mathrm{ml}$ & \\
\hline Day 33 & 29.4 .19 & LMP 25.4.19 & & $\begin{array}{l}\text { Tab ovulac LD OCP for contraception } \\
\text { started }\end{array}$ \\
\hline Day 38 & 4.5 .19 & & $1166.53 \mathrm{mIU} / \mathrm{ml}$ & \\
\hline Day 44 & 11.5 .19 & $\begin{array}{l}\text { Spotting } \mathrm{p} / \mathrm{v} \text { sometime } \\
\text { Pain in lower abdomen }\end{array}$ & & $\begin{array}{l}\text { Nagkesara churna } 3 \mathrm{gm} \\
\text { Sphatika bhasma } 500 \mathrm{mg} \\
\text { b. d }\end{array}$ \\
\hline Day 48 & 15.5.19 & Relief in previous complaints & & $\begin{array}{l}\text { Stop Nagkesara churna\& } \\
\text { Sphatika bhasma } \\
\text { Continue rest treatment as it }\end{array}$ \\
\hline Day 54 & 21.5 .19 & Relief in previous complaint & $865.75 \mathrm{mIU} / \mathrm{ml}$ & Continue same treatment \\
\hline Day 74 & 10.6 .19 & $\begin{array}{l}\text { LMP 28.5.19 stop in } 5 \text { days } \\
\text { Pad } 2 / \text { day }\end{array}$ & $572.56 \mathrm{mIU} / \mathrm{ml}$ & $\begin{array}{l}\text { Arbudhara kwatha } 10 \text { gm orally in } \\
\text { kwatha form } \\
\text { Raktaprasadaka him } 10 \text { gm O.D At } \\
\text { Approx } 10 \mathrm{am}\end{array}$ \\
\hline Day 100 & 6.7 .19 & LMP 23.6.19 & $408.47 \mathrm{mIU} / \mathrm{ml}$ & $\begin{array}{c}\text { yoga basti with Dashmoola taila } 60 \mathrm{ml} \\
\text { for Anuvasana basti and jwarahara } \\
\text { kwatha for Asthapana basti from } \\
11.7 .19 \text { to } 19.7 .19\end{array}$ \\
\hline Day 120 & 27.7 .19 & $\begin{array}{c}\text { LMP 21.7.19 } \\
\text { Nausea, Lower abdominal pain sometimes }\end{array}$ & & $\begin{array}{c}\text { Tab containing herbomineral drugs } 1 \text { tab } \\
\text { b. } \mathrm{d} \text { after meal and yoni pichu with } \\
\text { apamarga kshara taila in } 2 \text { alternate } \\
\text { days }\end{array}$ \\
\hline Day 147 & 23.8 .19 & LMP 19.8.19 No fresh complaint & $295.80 \mathrm{mIU} / \mathrm{ml}$ & Continue same treatment \\
\hline Day 166 & 12.9 .19 & LMP & $13.20 \mathrm{mIU} / \mathrm{ml}$ & Continue same treatment \\
\hline Day 205 & 21.10 .19 & LMP 18.10.19 & $364.00 \mathrm{mIU} / \mathrm{ml}$ & $\begin{array}{c}\text { yoga basti start from } 29 \text { November } \\
2019 \text { with triphala taila } 60 \mathrm{ml} \text { for } \\
\text { Anuvasana basti and Arbudhara kwatha } \\
\text { for Asthapana basti } \\
\text { Nidana Parivarjana and } \\
\text { Prakritivighata was strictly advised to } \\
\text { stop non vegetarian diet and advised to } \\
\text { take fresh green leafy vegetables like } \\
\text { Patol, methi, palak, Karela, moong dal } \\
\text { and Barley daliya } \text { or any Preparation of } \\
\text { Barley }\end{array}$ \\
\hline Day 230 & 16.11 .19 & LMP 5.11.19 & $83.17 \mathrm{mIU} / \mathrm{ml}$ & $\begin{array}{l}\text { Again, yoga basti start from } 29.11 .19 \text { to } \\
6.12 .13 \text { with triphala taila } 60 \mathrm{ml} \text { for } \\
\text { Anuvasana basti and Arbudhara kwatha } \\
\text { for Asthapana basti }\end{array}$ \\
\hline Day 255 & 11.12 .19 & LMP 7.12.19 & $\begin{array}{l}1.20 \mathrm{mIU} / \mathrm{ml} \\
\text { UPT Negative }\end{array}$ & $\begin{array}{l}\text { Finally, BHCG was found to be less } \\
\text { than } 1.20 \mathrm{mIU} / \mathrm{ml} \\
\text { In follow up same treatment continue } \\
\text { for } 2 \text { months }\end{array}$ \\
\hline
\end{tabular}


Table 2: Ingredients of Arbudhara kwatha

\begin{tabular}{|c|c|c|c|c|}
\hline S. No. & Name of Drug & Latin name & Part used & Quantity \\
\hline 1 & Shigru twak & Moringa Oleifera & Bark & 1 part \\
\hline 2. & Varun twak & Crataeva nurvala & Bark & 1 part \\
\hline 3. & Kanchnar twak & Bauhinia variegata Linn. & Bark & 1 part \\
\hline 4. & Haridra kanda & Curcuma longa & root & 1 part \\
\hline
\end{tabular}

Table 3: Ingredients of Raktaprasadaka him

\begin{tabular}{|c|c|c|c|c|}
\hline S. No. & Name of Drug & Latin name & Part used & Quantity \\
\hline 1 & Sariva kanda & Hemidesmus indicus & Bark & 1 part \\
\hline 2. & Manjistha kanda & Rubia cordifolia Linn & Bark & 1 part \\
\hline 3. & Kakmachi Sarvanga & Solanum nigrum Linn & Whole plant & 1 part \\
\hline 4. & Bhumiamalaki Sarvanga & Phyllanthus urinaria & Whole plant & 1 part \\
\hline 5. & Usheer mula & Vitiveria zizanioides Linn & Root & 1 part \\
\hline
\end{tabular}

Then she had complained of occasional spotting through vagina and pain in lower abdomen. So, we added yoga basti with Dashmoola taila $60 \mathrm{ml}$ for Anuvasana basti and Jwarahara kwatha for Asthapana basti for 2 cycles in July and August. Meanwhile Beta-HCG was reducing significantly however it was raised at two or three occasion. Then treatment was changed and Raktaprasadaka hima $10 \mathrm{gm}$ was given in empty stomach, Tab containing herbomineral drugs (Kanchnar guggulu, Shweta mushali, Ark bhasma, Lavang, Rasa Karpura, Suvarna bhasma, Ras sindura, Abhraka bhasma, Panna bhasma, Hiraka bhasma, Tulsi) 1 tab two times per day after meal and yoni pichu with apamarga kshara taila in 2 alternate days. Her Beta-HCG value was $13.20 \mathrm{mIU} / \mathrm{ml}$ on 12 September 2019 and 226.77 on 5 October 2019.

Then Nidana Parivarjana and Prakritivighata was done and she was strictly advised to stop non vegetarian diet, intake of fresh green leafy vegetables like Patol, methi, palak, Karela, moong dal and Barley daliya or any preparation of Barley. Finally, we planned for yoga basti on 29 November 2019 with Triphala taila $60 \mathrm{ml}$ for Anuvasana basti and Arbudhara kwatha for Asthapana basti. Now Beta-HCG was finally reduced to $1.20 \mathrm{mIU} / \mathrm{ml}$ on $11 / 12 / 2019$ and UPT was negative and patient got complete relief. Her follow up were taken for consecutive 3 month and Beta-HCG was found to be less than $1.20 \mathrm{mIU} / \mathrm{ml}$ and UPT was also negative.

\section{Basti procedure}

Triphala oil for Anuvasana Basti $(60 \mathrm{ml})$ and Arbudhara kwatha decoction for Niruha Basti $(350 \mathrm{ml})$, honey (30 $\mathrm{ml})$, Saindhava Lavana (rock salt) (5 g), Triphala oil (60 ml), Shatpushpa powder (20 g).

\section{Poorvakarma}

\section{Preparation of the patient}

On each day, patient was subjected to lower part body massage with Tila taila for 25-30 min followed by mild fomentation for 5-10 min for 8 days. After recording the vitals, the patients were advised to lie comfortably in the left lateral position on table.

\section{Preparation of Basti Dravya}

\section{Anuvasana Basti}

Shatpushpa powder and rock salt (Saindhava Lavana) each $1 \mathrm{~g}$ is mix with lukewarm Triphala oil $(60 \mathrm{ml})$ and is filled in syringe after that with the help of rubber tube catheter no. 8 basti is given.

\section{Niruha Basti}

In round bowl Honey $(30 \mathrm{ml})$ and rock salt (Saindhava Lavana) $(5 \mathrm{~g})$ was mixed up to disappearance of sound. Lukewarm Triphala oil $(60 \mathrm{ml})$ was mix in it and continuous triturating done till homogenous mixture was formed.

Then, Shatpushpa Kalka (paste $20 \mathrm{~g}$ ) was mixed properly in it. Afterward, lukewarm Arbudhara kwatha decoction $(350 \mathrm{ml})$ was added in it and mix well until homogenous mixture was formed. Then filled into Basti Putaka (enema pot)

\section{Pradhanakarma}

\section{Method of administration of Basti Dravya}

Catheter fitted with syringe (in Anuvasana basti) or enema pot (in Niruha basti) was inserted into the anus after lubricating it with oil. Oil was pushed into the rectum when piston of the syringe was pressed slowly. Patient was advised to take deep breath until the procedure is completed. Then, the patient was advised to lie down in the supine position with hand and legs freely spread over the table. After basti the legs of the patient were raised for three times; the buttocks were gently tapped, simultaneously taps were given on the soles and palm also. During course of Basti procedure, patient was advised to take lukewarm water, avoid heavy and oily food items traveling or, heavy exercise and suppression of natural urges.

\section{Outcome}

Beta HCG was decreasing consequently and within normal range after treatment. Urine pregnancy test was also negative; relief in previous symptoms of pain in lower abdomen, Nausea, weakness. In follow up period for consecutive 3 month and Beta-HCG was found to be less than $1.20 \mathrm{mIU}$. (Table 1)

\section{DISCUSSION}

Methotrexate (MTX), formerly known as amethopterin, is a chemotherapeutic and immuno suppressant agent. It is used to treat cancer, autoimmune diseases, ectopic pregnancy and for medical abortions ${ }^{9}$. Common side effects include nausea, feeling tired, fever, increased risk of infection, low white blood cell counts and breakdown of the skin inside the mouth. Other side effects may include liver disease, lung disease, lymphoma and severe skin rashes ${ }^{10}$. It acts by blocking the body's use of folic acid. Although patient was explained for prognosis and advised to take methotrexate therapy, but Patient and his close family denied pursuing methotrexate, instead of that, they opted for Ayurvedic treatment and we started the planned treatment protocol after proper consent of patient and their family members. 
Even though patient was advised to avoid sexual contact but OCP Tablet Ovuloc LD (Desogestrel $(0.15 \mathrm{mg})+$ Ethinyl Estradiol $(0.02 \mathrm{mg})$ was started for contraception. It is a very small dose contraceptive.

As the patient is coming with complaint of raised beta-HCG after D \& C; so, she we planned for D \& C again which was the line of treatment in this case. But after that procedure also beta-HCG levels not reduce. So, we manage patient with Ayurvedic treatment.

On the basis of symptomatology, Hydatidiform mole may resemble with Raktaja gulma. To keep the fact that it is a follow up case of Hydatidiform mole (Raktaja gulma) with the vitiation of Pitta dosha along with vata and kapha. We had planned Tridosha hara treatment protocol.

Avipatikara Churna has fourteen different ingredients which are: Shunthi (Zingiber officinale Roxb), Maricha (Piper nigrum Linn), Pippali (Piper longum Linn), Haritaki (Terminalia chebula Retz), Vibhitaki (Terminalia bellerica Roxb), Amalaki (Emblica officinalis Gaerth), Musta (Cyprus rotundus Linn), Salt (Vida lavana), Vidanga (Embelia ribes Burmf), Ela (Elettaria cardamomum Maton), Patra (Cinnamomum tamala Nees and Eberm) Lavanga (Syzygium aromaticum Linn), Trivita (Operculina turpethum Linn) and Sharkara (Sugar candy) ${ }^{11}$. They are Ushna and laghu. They are also known to be Pitta kapha Shamaka. They are Agnidipak and Amapachak. It also works as Mridu Virechan which helps in Rakta Shodhan as acharya indicated laxative in Rakta gulma ${ }^{12}$.
The active principles from $T$. cordifolia enhance host immune system by increasing immunoglobulin. It has Tikta kashaya rasa (Bitter, Astringent), laghu, guru, snigdha guna, (Light, Heavy, Unctuous), ushna veerya (Hot potency), Madhura Vipaka, vishaghna (Anti-toxic) ${ }^{13}$. It has vatapitta- kapha nashaka, agnideepan properties ${ }^{14}$.

Earlier studies on Neem (Azadirachta indica) reported that plants and their constituents show inhibitory effects on the growth of malignant cells via modulation of cellular proliferation, apoptosis, tumour suppressor gene and various other molecular pathways ${ }^{15}$. Nimbolide a limonoid from Azadirachta indica inhibits proliferation and induces apoptosis of human choriocarcinoma (BeWo) cells ${ }^{16}$. Its properties are Tikta rasa, Ruksha guna, Sheeta virya, katu vipaka, grahi and pittanasaka ${ }^{17}$.

Vincaleukoblastine, an alkaloid originally derived from Vinca rosea by Cutts, Beer and Noble ${ }^{18,19}$ has a remarkable inhibitory effect upon the growth of human choriocarcinoma maintained in heterologous transplant in the hamster cheek pouch. Vincaleukoblastine has suppressed tumor growth and activity in five of eight women with methotrexate-resistant, metastatic trophoblastic disease ${ }^{20}$. Vinca rosea has laghu, ruksha guna, kashaya tikta rasa, katu vipaka, ushna virya properties. In Ayurvedic

classics, sariva (Hemidesmus indicus), Manjishtha (Rubia cordifolia), bhumi amalaki (Phyllanthus niruri), etc. has been reported for skin care, hepato-protective as well as cognitive enhancer. All these drugs have property of rakta shodhana.

Arbudhara kwatha is the preparation of NIA Pharmacy itself. It is used as antitumor and anticancer drug. (Table 4), (Table 5)

Table 4: Pharmacodynamics properties of Arbudhara kwatha

\begin{tabular}{|c|c|c|c|c|c|c|}
\hline S. No. & Drugs & Rasa & Guna & Virya & Vipaka & Dosha karma \\
\hline 1. & Shigru twaka $^{21}$ & $\begin{array}{c}\text { Madhura, Katu } \\
\text { (Kshariya), Tikta. }\end{array}$ & $\begin{array}{c}\text { Laghu, Ruksha, } \\
\text { Tikshna. }\end{array}$ & Ushna & Katu & Kaphavata shamaka \\
\hline 2. & Varun twaka $^{22}$ & Tikta, kashaya & Laghu, Ruksha & Ushna & Katu & Vatashleshma hara \\
\hline 3. & Kanchnar twak $^{23}$ & Kashaya & Laghu, Ruksha & Sheeta & Katu & Tridoshahara \\
\hline 4. & Haridra kanda $^{24}$ & Katu, Tikta & Ruksha & Ushna & Katu & Kaphapitta hara \\
\hline
\end{tabular}

Table 5: Properties and pharmacological action of the drugs in Arbudhara kwatha

\begin{tabular}{|c|c|c|c|}
\hline S. No. & Drugs & Properties & Pharmacological action \\
\hline 1. & Shigru twak & $\begin{array}{c}\text { Shophaghna, Sukarala, Chakshushya, Dipana,Hrdya, } \\
\text { Rochana, Samgrahi, Vishaghna, Vataghna }{ }^{25}\end{array}$ & $\begin{array}{c}\text { Anti-histaminic, abortifacient, anthelmintic, antiseptic, } \\
\text { aphrodisiac, astringent, cardiotonic, carminative, } \\
\text { stomachic and tonic. It is used in general anasarca, } \\
\text { cancerous growth, glandular diseases, intermittent fever }\end{array}$ \\
\hline 2. & Varun twak & Bhedi, Dipana, Gulma hara & $\begin{array}{c}\text { Stomachic, laxative, antilithic, anthelmintic, bechic, } \\
\text { expectorants; antipyretic, sedative and tonic }{ }^{26} \text {. }\end{array}$ \\
\hline 3. & Kanchnar twak & $\begin{array}{c}\text { Dipana, Grahi, Krimighna, Kushthaghna, Gandamala } \\
\text { nashaka, Vranaropaka, Mehaghna and Raktapitta } \\
\text { Shamaka, Gandamala, Apachi, Vriddhihara }{ }^{27}\end{array}$ & $\begin{array}{c}\text { Anti-diabetic, anti-ulcer, antioxidant, nephroprotective, } \\
\text { anti-cancer, hepatoprotective, anti-inflammatory, } \\
\text { immunomodulatory, anti-microbial, anti-bacterial }{ }^{28} \text {. }\end{array}$ \\
\hline 4. & Haridra kanda & $\begin{array}{c}\text { Krimighana, Kushthaghna, vishaghna, varnya, } \\
\text { pramehnasak }\end{array}$ & $\begin{array}{c}\text { anti-inflammatory, antioxidant, anti-mutagenic, anti- } \\
\text { diabetic, antibacterial, hepatoprotective, expectorant and } \\
\text { anticancerous }\end{array}$ \\
\hline
\end{tabular}

Arbudhara kwatha has katu, tikta rasa, laghu ruksha guna, katu vipaka and Tridosha hara property. It also exhibits Amapachana, Shroto-Shodhaka and Vatanulomana activity which plays important role in Samprapti-Bhanga (to break the pathogenesis). Katu Rasa is formed by Vayu and Agni Mahabhuta, ${ }^{30}$ and Tikta rasa is a combination of Vayu and Akasha Mahabhuta ${ }^{31}$ respectively having properties of Deepan, Pachan, Lekhana, Kleda, Meda, Vasa, Pitta and Kapha shoshna ${ }^{32}$ Shothaghana, Kandughna and Upachaya-Abhishyanda-Kleda-Sneha Upahanti, Masam Vilikhati properties ${ }^{33}$. Laghu, Ruksha Guna pacifies vitiated Kapha and Kleda and supports the function of the other Rasas. Ushna virya directly effect on Jatharagni and Dhatwagni.
By these properties it decreases Meda dhatu and also prevents condition of endometrial hyperplasia; as, Beta HCG is secreted by trophoblast, so our main aim is the formation of normal endometrium and removal of trophoblast. Lekhana and Arbudhara property of Kashaya helps in formation of normal endometrium and thus results in reducing Beta HCG.

As Arbudhara kwatha possess Antitumor and Anticancer activities. It has been found that niazimicin, a thiocarbamate from Moringa oleifera, exhibits inhibition of tumor promote-induced Epstein-Barr virus activation ${ }^{34}$. The methanol fraction of Moringa oleifera leaf showed hepatoprotective and anticoagulant 
effect in rats. Roots have also been reported to have hepatoprotective activities ${ }^{35}$. In vitro and animal studies indicate that the leaf, seed and root extracts of Moringa oleifera have anticancer, hepatoprotective, hypoglycemic, anti-inflammatory, antibacterial, antifungal and antiviral, help lower cholesterol level and promote wound healing ${ }^{36}$. Crataeva nurvala is highly effective in lymph adenitis (Gandamala nasan) and immature wound healing (Apakva Vidradhi) etc. It has diuretic, antimalarial, antipyretic, sedative and hepato-protective, anti-diabetic and anti-ulcer activity. In vitro study revealed that Bauhinia variegate extract showed anti-cancer activity by inhibiting the growth of these cell lines ${ }^{37}$ curcumin affects a variety of growth factor receptors and cell adhesion molecules involved in tumor growth, angiogenesis and metastasis ${ }^{38}$. Curcumin is known for its synergic effect as anti-cancer agent.

\section{CONCLUSION}

Management for follow up case of vesicular mole appears to be a possible, high-risk alternative to methotrexate and should only be in those women who refuse standard management of taking methotrexate. Therefore, strict patient selection is of paramount importance since it may be associated with a higher risk of morbidity. Sequential changes in serum beta-HCG and ultrasonograpy can be used as combined methods for the followup of such type of cases. Ayurvedic treatment regimens which possess Antitumor and Anticancer activities like Arbudhara $k w a t h a$ are helpful in managing such type of cases. Also, there is possibility to avoid second time D \& C, if we start Ayurvedic management soon after first $\mathrm{D} \& \mathrm{C}$ in such type of cases. This will also help us to avoid complication originated by invasive procedures.

\section{Patient consent}

Written consent for publication of this case study was obtained from the patient.

\section{REFERENCES}

1. Gestational Trophoblastic Disease at American Cancer Society. Last Medical Review: 04/14/2011

2. Cotran RS, Kumar V, Fausto N, Nelso F, Robbins SL, Abbas AK. Robbins and Cotran pathologic basis of disease (7th ed). St. Louis, Mo: Elsevier Saunders; 2005. p. 1110. ISBN 07216-0187-1

3. Merriam Webster. Hydatidiform mole Retrieved May 7; 2012.

4. Cavaliere A, Ermito S, Dinatale A, Pedata R. Management of molar pregnancy. J Prenat Med 2009; 3(1): 157. PMC 3279094. PMID 22439034

5. Cotran RS, Kumar V, Fausto N, Nelso F, Robbins SL, Abbas AK. Robbins and Cotran pathologic basis of disease (7th ed). St. Louis, Mo: Elsevier Saunders; 2005. p. 1112. ISBN 07216-0187-1.

6. Sushruta. Gulma pratished Adhyaya. In: Shastri AD, editors. Sushruta Samhita. Revised edition. Varanasi (India): Chaukhamba Sanskrit Sansthan; 2016. p. 264.

7. Charaka, Gulma chikitsa adhyaya. In: Pandey K, Chaturvedi G, editors. Charaka Samhita. Revised edition. Varanasi (India): Chaukhambha Bharati Academy; 2015. p. 225.

8. Satyapala, Kashyapa Samhita, Panchakarmiya Siddhi sthana, Chaukhambha Bharatiya Academy, 2nd edition, Varanasi; 1998. p. 167.

9. Methotrexate. The American Society of Health-System Pharmacists. Archived from the original on 2016-10-08. Retrieved 22 Aug 2016.
10. Methotrexate. The American Society of Health-System Pharmacists. Archived from the original on 2016-10-08. Retrieved 22 Aug 2016.

11. The Ayurvedic Formulation of India, part I, second revised English edition, Government of India, Bhaishajya Ratnavali, Amlapittadhikara, 106.

12. Charaka, Gulma chikitsa Adhyaya. In: Pandey K, Chaturvedi G, editors. Charaka Samhita. Revised edition. Varanasi (India): Chaukhambha Bharati Academy; 2015. p. 221.

13. Sharma PV. Dravya guna Vigyan (Vegetable Drugs) 1st ed. Vol. II. Varanasi: Chaukhambha Bharati Academy; 2003. p. 761-3.

14. Tripathi RD. Ashtanga Sangraha (Sutra sthana) Varanasi: Chaukhambha Sanskrit Pratishthan; 2006. p. 142-315.

15. H. Rahmani, M. A. Alzohairy, M. A. Khan and S. M. Aly. Therapeutic implications of black seed and its constituent thymoquinone in the prevention of cancer through inactivation and activation of molecular pathways, EvidenceBased Complementary and Alternative Medicine, vol. 2014, Article ID 724658, 13 pages; 2014.

16. G. Harish Kumar, K.V.P. Chandra Mohan, A. Jagannadha Rao and S. Nagini Preclinical Studies Nimbolide a limonoid from Azadirachta indica inhibits proliferation and induces apoptosis of human choriocarcinoma (BeWo) cells Published: 22 August 2008 Investigational New Drugs volume 27; 2009. p. 246-252.

17. Anonymous. The Ayurvedic Pharmacopeia of India, Ministry of Health and Family Welfare, Government of India, New Delhi, part 1 Vol -2. p. 132.

18. Cutts, J.1.; Beers, C. W. and Noble, R. L. Effects on Hematopoiesis in Rats of Extracts of Vinca rosea. Rev. Can. Biol 1957; 16: 476.

19. Noble R. L., Beers, C. T. and Cutts, J.I. Role of Chance Observations in Chemotherapy: Vinca rosea. Ann. N.Y. Acad. Sc., 1958; 76: 88 -94.

20. Royhertz M. B. Lipsett, Andr. H. Mo Y Effect of Vincaleukoblastine on Metastatic Choriocarcinoma and Related Trophoblastic Tumors in Women (Endocrinology Branch, National Cancer Institute, Bethesda, IFD.)

21. Prof. P. V. Sharma, Dravya guna-Vijnana, Vol. II, Vegetable Drugs, Reprint, Chaukhambha Bharati Academy, Varanasi; 2006. p. 111-114.

22. Prof. P. V. Sharma, Dravya guna-Vijnana, Vol. II, Vegetable Drugs, Reprint, Chaukhambha Bharati Academy, Varanasi; 2006. p. 652.

23. Prof. P.V. Sharma, Dravya guna-Vijnana, Vol. II, Vegetable Drugs, Reprint, Chaukhambha Bharati Academy, Varanasi; 2006. p. 234.

24. Prof. P. V. Sharma, Dravya guna-Vijnana, Vol. II, Vegetable Drugs, Reprint, Chaukhambha Bharati Academy, Varanasi; 2006. p. 162.

25. Anonymous. The Ayurvedic Pharmacopeia of India, Ministry of Health and Family Welfare, Government of India, New Delhi, part 1 Vol-4; 2001. p. 130.

26. Kirtikar K.R and Basu B.D, Indian medicinal plant, Text vol.1; 2005. p. 192.

27. Anonymous. The Ayurvedic Pharmacopeia of India, Ministry of Health and Family Welfare, Government of India, New Delhi, part 1, Vol-1; 2001.p. 74.

28. Tewari Ramesh Chandra et al. Kanchnar (Bauhinia variegata Linn.): A Critical review IJAPR 2015; Vol 3(7).

29. Vasavda Krup, Hedge Prakash L and Harini A. Pharmacological Activities of Turmeric (Curcuma longa Linn): A Review Journal of Traditional Medicine and Clinical Naturopathy ISSN: 2573-4555

30. Charaka, Atreyabhadrakapiya Sutra Sthana. In: Pandey K, Chaturvedi G, editors. Charaka Samhita. Revised edition. 
Varanasi (India): Chaukhambha Bharati Academy; 2015. p. 503.

31. Charaka, Atreyabhadrakapiya Adhyaya Sutra sthana. In: Pandey K, Chaturvedi G, editors. Charaka Samhita. Revised edition. Varanasi (India): Chaukhambha Bharati Academy; 2015. p. 503.

32. Charaka, Atreyabhadrakapiya adhyaya Sutra sthana. In: Pandey K, Chaturvedi G, editors. Charaka Samhita. Revised edition. Varanasi (India): Chaukhambha Bharati Academy; 2015. p. 507.

33. Charaka, Atreyabhadrakapiya Adhyaya Sutra sthana. In: Pandey K, Chaturvedi G, editors. Charaka Samhita. Revised edition. Varanasi (India): Chaukhambha Bharati Academy; 2015. p. 507.

34. Charaka, Atreyabhadrakapiya Adhyaya Sutra sthana. In: Pandey K, Chaturvedi G, editors. Charaka Samhita. Revised edition. Varanasi (India): Chaukhambha Bharati Academy; 2015. p. 506.

35. Murakami A, Kitazono Y, Jiwajinda S, Koshimizu K, Ohigashi H. Niazimicin, a thiocarbamate from the leaves of Moringa oleifera Lam holds a strict structural requirement for inhibition of tumour-promoter-induced Eostein-Barr virus activation. Planta Med 1998; 64: 319- 323.

36. Ruckmani K, Kavimani S, Anandan R, Jayakar B. Effect of Moringa oleifera on Paracetamol induced hepatotoxicity. Indian J Pharm Sci 1998; 60: 33-35.

37. http://www.mskcc.org/cancercare/integrativemedicine/discla imer?msk disclaimer herb $=1 \&$ destination $=\% 2$ Fcancercare $\% 2$ Fherb\%2Fmoringa-oleifera.

38. Kulshrestha PK, Mishra AK, Pal VK, Pandey S, Tripathi D, Yadav P. The antimicrobial activity of Bauhinia variegata Linn. Flower extract (methanolic). Asian J Pharma Clin Res 2011; 4(1): 46-47.

39. Wilken R. Curcumin: A review of anti-cancer properties and therapeutic activity in head and neck squamous cell carcinoma. Mol Cancer 2011; 10: 12.

\section{Cite this article as:}

Poonam Choudhary et al. Effect of Ayurvedic regimen on elevated Beta-HCG levels in hydatidiform mole after induction of Garbhapata: A Case Study. Int. J. Res. Ayurveda Pharm. 2020;11(4):12-17 http://dx.doi.org/10.7897/2277-4343.110479

Disclaimer: IJRAP is solely owned by Moksha Publishing House - A non-profit publishing house, dedicated to publishing quality research, while every effort has been taken to verify the accuracy of the content published in our Journal. IJRAP cannot accept any responsibility or liability for the site content and articles published. The views expressed in articles by our contributing authors are not necessarily those of IJRAP editor or editorial board members. 